\title{
Electrophoretic pattern of serum proteins in horses with babesiosis
}

\author{
Patrón electroforético de proteínas séricas en caballos con babesiosis \\ R Barrera, MV Carapeto, MA Habela, C Zaragoza* \\ Department of Medicine and Health Animal, Faculty of Veterinary Sciences, University of Extremadura, Spain.
}

\begin{abstract}
RESUMEN
La electroforesis sérica en hojas de acetato de celulosa es una técnica que se usa frecuentemente para separar las distintas fracciones proteicas. Esta técnica permite detectar cambios cualitativos y cuantitativos en las proteínas séricas relacionados con distintas enfermedades. El propósito de este estudio fue caracterizar los cambios que se producen en las distintas fracciones proteicas en caballos con babesiosis con el fin de evaluar su aplicación en el diagnóstico de la enfermedad. En este trabajo se han calculado las concentraciones de proteínas totales de 53 caballos y se ha realizado electroforesis sérica de estos animales. Los caballos fueron divididos en dos grupos: Grupo I (19 caballos sanos) y Grupo II (34 caballos con babesiosis clínica). La enfermedad fue diagnosticada por inmunofluorescencia indirecta. Los resultados obtenidos en el grupo de caballos enfermos se compararon con los mostrados por los caballos sanos. Las medianas estadísticas para la concentración de proteínas totales y la fracción de $\gamma$-globulinas fueron estadísticamente más altas $(\mathrm{P}<0,01)$ que las observadas en el grupo control. Además, la subfracción de $\alpha_{2}$-globulina en los caballos enfermos mostró también un aumento estadísticamente significativo $(\mathrm{P}<0,05)$ con respecto a los caballos sanos. Los resultados obtenidos en este estudio permiten concluir que la alteración más significativa observada en el patrón sérico de proteínas en caballos con babesiosis es el aumento de las $\alpha_{2}$-y las $\gamma$-globulinas.
\end{abstract}

Key words: electrophoresis, serum, babesiosis, horse.

Palabras clave: electroforesis, suero, babesiosis, caballo.

\section{INTRODUCTION}

Serum electrophoresis is a common technique of laboratory diagnosis in human medicine, as well as in small animal medicine. There are different techniques of electrophoresis but the most common method in clinical medicine is zone electrophoresis (Batamuzi et al 1996, Thomas 2000). It is characterized because the serum is placed on a supporting medium such as cellulose acetate. Serum proteins have a negative charge, so they migrate in an electric field and can be separated from each other in different bands (zones). Each band is made up of a group of individual proteins which can be identified by this technique (Barta and Pourciau 1984). Although this technique provides very useful information about the quantitative alterations of the serum protein fractions related to the disease, it is not commonly used in equine medicine.

Serum electrophoresis from healthy horses is characterized by the absence of prealbumin region and by six different bands: albumin, $\alpha_{1}$-globulins, $\alpha_{2}$-globulins, $\beta_{1}$-globulins, $\beta_{2}$-globulins and $\gamma$-globulins (Kohn 1997). However, in the disease such as in equine babesiosis, the serum concentration of the proteins can change significantly (Kumar et al 2002).

Equine babesiosis is a tick-borne protozoal disease caused by Babesia caballi and Babesia equi. Although it has been

Accepted: 14.07.2010.

* Avda. Universidad s/n 10071, Cáceres, Spain; zaragoza@unex.es reported that horses are most susceptible to infection, the disease can affect horses, donkeys, their hybrids and wild equidae (Okamura et al 2005, 2007). The disease may take on an acute or chronic form (Radostits et al 1999). Clinical signs of the acute form include weakness, anorexia, fever of up to $42^{\circ} \mathrm{C}$, which usually becomes irregular after the second day (Malikides et al 2000). Animals that have the chronic form of the illness usually survive for months without any apparent signs of the disease. Symptoms may include steady weight loss and slight anaemia usually following exercise or stress situations (Hailat et al 1997).

Babesiosis is an important disease from both economic and animal health point of view, because it involves substantial losses by death and by decrease in animal production. In addition, the equestrian legislation of some countries do not allow seropositive symptomatic and nonsymptomatic animals (Asenzo et al 2008).

Horses with babesiosis often display an increase in the concentration of total proteins usually caused by dehydration and by the increase in the $\gamma$-globulin concentration (Kumar et al 2002). However, until now zone-electrophoresis to evaluate changes in protein fractions has not been applied to the serum in equine babesiosis, although it is very useful from a clinical point of view because it is less time consuming.

The aim of the present work was characterize the serum electrophoretic pattern in horses suffering from babesiosis and to evaluate its application in the diagnosis by the study of the quantitative alterations in the serum proteins associated to this disease. 


\section{MATERIALS AND METHODS}

\section{ANIMALS}

Fifty three adult horses of different breed, sex, and age were studied and classified in two groups. Group I included 19 healthy horses all seronegative to babesiosis. Animals from Group II were presented to the Veterinary Teaching Hospital at Extremadura University (Spain) showing clinical symptoms consistent with the disease (table 1). This group included 34 horses suffering from naturally acquired babesiosis: 7 horses $(20.59 \%)$ showed positive antibody titre against Babesia caballi, 9 horses (26.47\%) against Babesia equi and 18 horses (52.94\%) showed positive titre against both Babesia species (Table2). Disease was always diagnosed or ruled out by indirect immunofluorescence antibody assay.

\section{SEROLOGICAL TESTS}

Serological tests were performed according with Callow et al (1979), Donnelly et al (1980 a, b), Soule et al (1984), and Habela et al (1989). Antigen of Babesia equi was prepared after esplenectomized carrier horse (titre 1/320) from Andalucía (local strain), and the antigen of Babesia caballi after infection with USDA strain of seronegative horse, which was kindly provided for Professor G. Uilenberg (Veterinary Faculty, Utrecht, Netherlands). Commercial fluorescein conjugated rabbit anti-horse immunoglobulin (Nordic, Tilburg, Netherlands) was used at a dilution of 1:60 in phosphate-buffered saline. A titre of 1:80 was considered positive. Positive and negative control sera were kindly supplied by Professor G. Uilenberg (Veterinary Faculty, Utrecht, Netherlands).

\section{SERUM TOTAL PROTEIN}

Blood samples were obtained under non-stress conditions by jugular venipuncture using vacutainer tubes. Serum was obtained by centrifugation for 10 minutes at $600 \mathrm{~g}$ using serum-separator tubes. Serum was used instead of plasma in order to avoid interference from fibrinogen. Serum protein concentration was calculated by Biuret's method (Gornall et al 1949). Freeze-dried bovine serum albumin (Química Clínica Aplicada, Spain) was used as a control.

\section{SERUM ELECTROPHORESIS}

To characterize the serum electrophoretic pattern in the animals studied, serum electrophoresis was performed. Zone electrophoresis (Kohn 1957) on a supporting medium of cellulose acetate strips $(2.5 \times 17 \mathrm{~cm})\left(\right.$ Cellogel $^{\circledR}$, Atom Biosystems, Spain) was performed. Serum proteins migrated in an electric field of 200 volts for 65 minutes. The buffering solution used was sodium veronal $0.04 \mathrm{M}$ and sodium-dietilbarbiturate $0.82 \mathrm{~g} / \mathrm{dl}$. Amido-Black
(Atom Biosystems, Spain) staining was used, and a solution of methanol, acetic acid, and water (40:10:50) was applied as a destaining solution. Finally, the strips were analyzed in a scanner densitometer using the Ultroscan GSX software (Pharmacia LKB Biotechnology, San Francisco, CA, USA).

\section{STATISTICAL ANALYSIS}

Statistical analysis of the results was performed using the non-parametric of Mann-Whitney U test. The used software was SPSS 14 (SPSS, Inc., Chicago, IL, USA).

Table 1. More significant clinical manifestations noted in the Group II (horses with babesiosis).

Manifestaciones clínicas más significativas observadas en el Grupo II (caballos con babesiosis).

\begin{tabular}{|c|c|c|c|c|c|c|c|}
\hline $\begin{array}{l}\text { Horse } \\
\mathrm{N}^{0}\end{array}$ & Weakness & Anorexia & Fever* & $\begin{array}{c}\text { Steady } \\
\text { weight } \\
\text { loss }\end{array}$ & $\begin{array}{c}\text { Pale } \\
\text { mucous } \\
\text { mem- } \\
\text { branes }\end{array}$ & Jaundice & Oedemas \\
\hline 1 & - & - & - & + & - & - & - \\
\hline 2 & - & + & + & - & - & + & + \\
\hline 3 & + & + & + & - & - & + & + \\
\hline 4 & - & + & + & - & + & + & - \\
\hline 5 & - & - & - & + & - & - & - \\
\hline 6 & - & - & - & + & - & - & - \\
\hline 7 & + & + & - & + & + & + & - \\
\hline 8 & + & + & + & - & + & + & - \\
\hline 9 & - & - & - & + & - & - & - \\
\hline 10 & - & - & + & - & + & - & - \\
\hline 11 & + & + & - & + & + & - & - \\
\hline 12 & - & - & - & - & - & - & - \\
\hline 13 & - & - & - & + & + & - & - \\
\hline 14 & - & + & - & - & - & - & - \\
\hline 15 & + & + & + & + & + & + & + \\
\hline 16 & + & + & + & - & + & + & - \\
\hline 17 & - & + & - & - & - & - & - \\
\hline 18 & + & + & + & - & + & + & - \\
\hline 19 & + & + & - & + & - & - & - \\
\hline 20 & - & - & - & - & + & - & - \\
\hline 21 & + & + & - & + & - & - & - \\
\hline 22 & - & - & - & + & - & - & - \\
\hline 23 & + & + & - & + & + & + & - \\
\hline 24 & - & - & - & - & - & - & - \\
\hline 25 & + & + & + & - & - & + & - \\
\hline 26 & + & + & + & - & - & + & - \\
\hline 27 & + & + & - & + & - & - & - \\
\hline 28 & - & - & - & + & + & - & - \\
\hline 29 & + & + & - & + & + & + & - \\
\hline 30 & + & + & + & + & + & + & - \\
\hline 31 & + & + & + & - & - & + & - \\
\hline 32 & + & + & - & + & + & + & - \\
\hline 33 & - & + & + & - & + & + & - \\
\hline 34 & + & + & + & - & + & + & - \\
\hline
\end{tabular}

* Body temperature up to $39^{\circ} \mathrm{C}$. 


\section{RESULTS}

GROUP I

Serum electrophoresis from Group I showed a normal electrophoretic pattern, characterized by six different bands: albumin, $\alpha_{1}$-globulin, $\alpha_{2}$-globulin, $\beta_{1}$-globulin, $\beta_{2}$-globulin and $\gamma$-globulin fractions (figure 1 ). Statistical analysis results of serum protein fractions from Group I are shown in table 3 .

GROUP II

In our study, the median obtained for the serum total proteins in the Group II was $7.18 \mathrm{~g} / \mathrm{L}$ (interquartile range (IQR) 5.80-9.03 g/L), showing a statistically significant difference $(\mathrm{P}<0,001)$ with the Group I (table 3$)$. Although, the range of values obtained was very wide (minimum value $=36 \mathrm{~g} / \mathrm{L} ;$ maximum value $=142.7 \mathrm{~g} / \mathrm{L}$ ), hyperproteinemia was observed in 14 horses. Conversely, six animals showed hypoproteinemia with a serum total protein concentration lower than $55 \mathrm{~g} / \mathrm{L}$.

Although the median albumin concentration was $3.96 \mathrm{~g} / \mathrm{L}, 13$ horses with babesiosis displayed high values of the albumin concentration. Statistical data obtained for the concentration albumin in Group II are shown in table 3 .

In this group, the $\alpha$-globulin fraction was also resolved into two subfractions: $\alpha_{1}$-globulin and $\alpha_{2}$-globulin, respectively. The $\alpha_{1}$-globulin values from sick horses were similar to the results obtained in healthy horses for the same subfraction. Conversely, a statistically significant increase $(\mathrm{P}<0,005)$ in the median $\alpha_{2}$-globulin sub-fraction was observed in Group II (table 3). Fourteen of the 34 horses studied, showed high values of $\alpha_{2}$-globulin sub-fraction, mainly 5 of them (figure 2).

The $\beta$-globulin fraction in horses with babesiosis was also resolved into two subfractions: $\beta_{1}$-globulin and $\beta_{2}$-globulin, respectively. Statistical results are shown in table 3 . The $\beta_{1}$ and $\beta_{2}$-globulin median from sick horses was similar to the results obtained in healthy horses for the same subfraction. Although 3 horses in particular, had an increase in the $\beta_{2}$-globulin and a decrease in $\beta_{1}$-globulin, 2 animals presented an increase in both sub-fractions and 9 horses showed a decrease in both sub-fractions.

The median value of the $\gamma$-globulins fraction obtained in the sick horses $(1.36 \mathrm{~g} / \mathrm{L})$ was significantly higher $(\mathrm{P}<0.01)$ than that obtained in Group I (table 3).

Finally, 12 of the sick animals displayed a ratio lower than 1 and a low albumin concentration was observed in the majority of them. The statistical results obtained for the albumin/globulin ratio in Group II are shown in table 3.

\section{DISCUSSION}

Hyperproteinemia in babesiosis is usually caused by dehydration, whose main cause is the letargy associated to the disease (Divers 1998). In addition, the increase in the $\gamma$-globulin concentration also contributes to the increase in the total proteins concentration (Radostits et al 1999). In our study, the median value obtained for the serum total proteins in the Group II was significantly higher $(\mathrm{P}<0.01)$ than that obtained in the Group I (table 3$)$. Hypoproteinemia observed in six animals may be related to the severe anorexia that characterizes the disease in its acute form, as well as the feverish symptoms displayed (table 1). In some cases, hypoproteinemia can be so severe

Table 2. Antibody titers for Babesia equi and Babesia caballi obtained by indirect immunofluorescence test (IFI) in the Group II (horses with babesiosis).

Títulos de anticuerpos frente a Babesia equi y Babesia caballi obtenidos mediante inmunofluorescencia indirecta (IFI) en el Grupo II (caballos con babesiosis).

\begin{tabular}{|c|c|c|c|c|c|}
\hline Horse $\mathrm{N}^{\mathrm{o}}$ & B. equi & B. caballi & Horse $\mathrm{N}^{\mathrm{o}}$ & B. equi & B. caballi \\
\hline 1 & $1 / 160$ & $1 / 160$ & 18 & $1 / 1280$ & Negative \\
\hline 2 & $1 / 640$ & $1 / 320$ & 19 & $1 / 160$ & $1 / 160$ \\
\hline 3 & $1 / 160$ & $1 / 320$ & 20 & $1 / 320$ & Negative \\
\hline 4 & $1 / 80$ & $1 / 320$ & 21 & $1 / 320$ & Negative \\
\hline 5 & $1 / 160$ & $1 / 160$ & 22 & Negative & $1 / 640$ \\
\hline 6 & Negative & $1 / 640$ & 23 & $1 / 160$ & Negative \\
\hline 7 & $1 / 320$ & $1 / 1280$ & 24 & $1 / 80$ & Negative \\
\hline 8 & Negative & $1 / 640$ & 25 & $1 / 160$ & $1 / 320$ \\
\hline 9 & Negative & $1 / 160$ & 26 & $1 / 160$ & Negative \\
\hline 10 & $1 / 640$ & $1 / 160$ & 27 & $1 / 80$ & $1 / 640$ \\
\hline 11 & Negative & $1 / 320$ & 28 & $1 / 640$ & Negative \\
\hline 12 & $1 / 80$ & $1 / 80$ & 29 & $1 / 1280$ & $1 / 640$ \\
\hline 13 & $1 / 640$ & Negative & 30 & $1 / 80$ & $1 / 640$ \\
\hline 14 & Negative & $1 / 320$ & 31 & $1 / 160$ & $1 / 320$ \\
\hline 15 & $1 / 320$ & $1 / 320$ & 32 & $1 / 1280$ & $1 / 160$ \\
\hline 16 & Negative & $1 / 1280$ & 33 & $1 / 160$ & $1 / 80$ \\
\hline 17 & $1 / 160$ & Negative & 34 & $1 / 320$ & $1 / 160$ \\
\hline
\end{tabular}




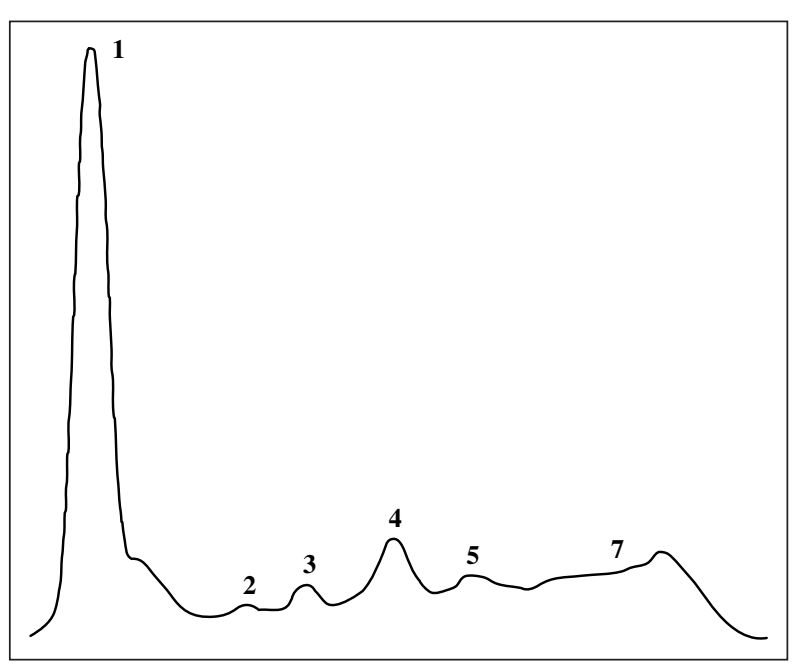

Figure 1. Densitometer scan of the serum electrophoresis of a healthy horse. 1: albumin; 2: $\alpha_{1}$-globulin; 3: $\alpha_{2}$-globulin; 4: $\beta_{1}$-globulin; 5: $\beta_{2}$-globulin; 6 : $\gamma$-globulins.

Lectura densitométrica de la electroforesis sérica de un caballo sano. 1: albúmina; 2: $\alpha_{1}$-globulina; 3: $\alpha_{2}$-globulina; 4: $\beta_{1}$-globulina; 5: $\beta_{2}$-globulina; 6: $\gamma$-globulinas.

that oedema in the limbs of 3 horses was observed in our study (table 1).

The median concentration of albumin in Group II was higher than that obtained in Group I, although nonstatistically significant difference was observed (table 3 ). The increase in the albumin concentration may be explained as a consequence of dehydration because no pathological processes with increase in the production of albumin have been described (Kaneko 1997). In order to produce clinical signs, it is considered that the serum albumin level must decrease until some values below $15.0 \mathrm{~g} / \mathrm{L}$. The presence of oedema was verified in the 3 horses that presented such values. The decrease of the albumin concentration in horses with babesiosis is related to the hepatopathy that may develop during the disease (Colville 2002) and to the symptomatic anorexic state (Stockham and Scott 2002) observed in 23 horses (table 1). Hypoalbuminemia is usually related to chronic cases and a prolonged course. Furthermore, the albumin concentration variation is usually associated to that of serum total proteins since it is the most abundant protein in the blood, as usually observed in the animals studied. However, in 5 of the 14 horses that showed an increase in serum total proteins, hyperalbuminemia was not the main cause of the increase, it was a severe hypergammaglobulinemia that had contributed noticeably to that increase.

The $\alpha$-globulin fraction are known as acute stage proteins because their concentration increases immediately after an inflammation or a wound (Stockham and Scott 2002). In horses, the concentration of $\alpha_{1}$-globulin is lower than $\alpha_{2}$-globulin (Kohn 1997), although functional differences between them have not been reported. These proteins are usually evaluated together and reference is made to the $\alpha$-globulin fraction without indicating the sub-fraction (Sevelius and Andersson 1995, Kaneko 1997). The $\alpha_{1}$-globulin median from the sick horses was similar to the results obtained in the healthy horses for the same subfraction (table 3 ). Changes of the $\alpha_{1}$-globulin concentration do not appear to be important from a diagnostic point of view. However, the median value for the $\alpha_{2}$-globulin subfraction in Group II was significantly higher $(\mathrm{P}<0.05)$ when compared with that obtained in Group I (table 3 ). The increase of the $\alpha$-globulin fraction occurs frequently in equidae suffering from different pathologies (Carapeto et al 2006). Although its increase has not been described in equine babesiosis, a clear increase in the $\alpha_{2}$-globulin sub-fraction was observed in five of the horses studied (figure 2). Although this increase is due to tissue damage and inflammatory processes, elevation of the $\alpha$-globulin fraction may be observed in diseases that are not linked to inflammation, such as occurs in cases of hepatic or renal damage (Kaneko 1997). This fact may explain the results observed in some of the horses studied because when a hepatopathy is developed, an increase in the $\alpha_{1}$-glycoprotein-acid, $\alpha_{1}$-antitrypsin, haptoglobin and $\alpha_{2}$-macroglobulin can be observed (Sevelius and Andersson 1995). In addition, animals with babesiosis frequently develop renal disease resulting from dehydration and haemoglobinuria by intra-vascular haemolysis produced by the parasite (Navarrete y Serrano 1999). Finally, the increase of $\alpha$-globulin fraction may be cut off by the decrease in the concentration of the haptoglobin, usually observed in animals with haemolytic anaemia, which characterizes the disease (Jain 1993).

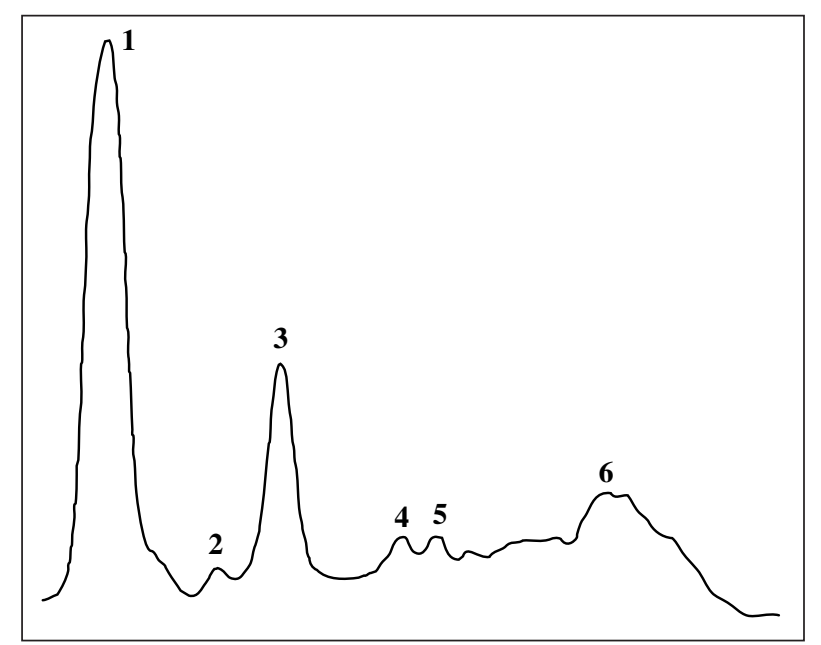

Figure 2. Densitometer scan of the serum electrophoresis of a horse with babesiosis showing an increase of the $\alpha_{2}$-globulin subfraction. 1: albumin; 2: $\alpha_{1}$-globulin; 3: $\alpha_{2}$-globulin; 4: $\beta_{1}$ globulin; 5: $\beta_{2}$-globulin; 6: $\gamma$-globulins.

Lectura densitométrica de la electroforesis sérica de un caballo con babesiosis mostrando un aumento en la fracción de $\alpha_{2}$-globulinas. 1: albúmina; 2: $\alpha_{1}$-globulina; 3: $\alpha_{2}$-globulina; 4: $\beta_{1}$-globulina; 5: $\beta_{2}{ }^{-}$ globulina; 6: $\gamma$-globulinas. 
When the results of $\beta$-globulin sub-fractions in horses with babesiosis were compared with those obtained in the control group, no significant differences were observed (table 3). Changes in this fraction depend on different factors, such as the progress of the disease (acute or chronic) and the course or severity of the haemolytic anaemia caused. In addition, an increase in its concentration related to acute hepatic damage has been described (Kaneko 1997) as a consequence of the increase in the transferrin concentration. This protein also contributes to the $\beta$-globulin decrease if the hepatic disease is chronic (Barta and Pourciau 1984). Conversely, horses suffering from babesiosis are characterized by haemolytic anaemia. Although this has not been confirmed in natural clinical processes, the $\beta$-globulin increase is a consequence of in vitro haemolysis caused by the presence of free haemoglobin. In addition, a decrease in the $\beta$-globulin concentration as a result of a decrease in the pepsin concentration in cases of clinical haemolysis has been described (Barta and Pourciau 1984). Horses with babesisosis occasionally show disseminated intra-vascular coagulation (Radostits et al 1999) that causes an increase in the plasminogen concentration, which is included in the $\beta$-globulin fraction. Finally, $\beta$-globulin fraction concentration may be related to the albumin fraction in cases of extravascular liquid exudation. This fact was observed in two of the horses that presented lower $\beta$-globulin values and hypoalbuminemia.

In babesiosis, the immunity mechanisms are mainly of humoral nature (Morris et al 2002), although the protozoa can activate a cellular-type immune response (Tizard 1996). In this study, the median value obtained for the $\gamma$-globulin fraction in sick horses was significantly higher $(\mathrm{P}<0.01)$ than the one obtained in healthy horses (table 3 ). This increase observed in the serum $\gamma$-globulin concentration (figure 3 ) is related to the humoral immunity activated by the parasitation of the animals

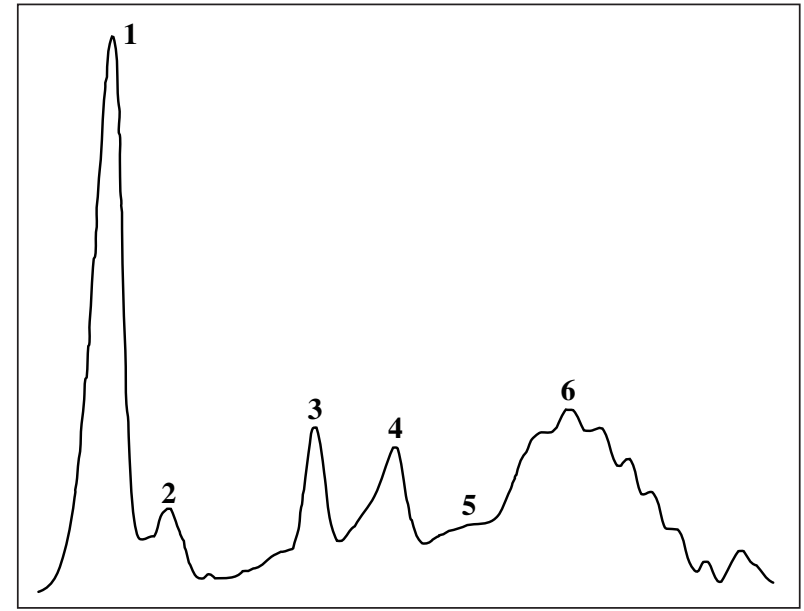

Figure 3. Densitometer scan of the serum electrophoresis of a horse with babesiosis showing an increase of the $\gamma$-globulin fraction. 1: albumin; 2 : $\alpha_{1}$-globulin; 3 : $\alpha_{2}$-globulin; $4: \beta_{1}$-globulin; 5: $\beta_{2}$-globulin; 6: $\gamma$-globulins.

Lectura densitométrica de la electroforesis sérica de un caballo con babesiosis mostrando un aumento en la fracción de $\gamma$-globulinas. 1: albúmina; 2: $\alpha_{1}$-globulina; 3: $\alpha_{2}$-globulina; 4: $\beta_{1}$-globulina; 5: $\beta_{2}$-globulina; 6: $\gamma$-globulinas.

studied. This occurs mainly in horses with a more severe hypergammaglobulinemia and hepatic damage, although the immune response in some animals may produce an increase of immunoglobulin too small to be detected through routine electrophoresis techniques (Jain 1993, Stockham and Scott 2002).

Finally, although one third of the sick animals displayed a albumin/globulin ratio lower than 1, the absence of statistically significant difference against healthy horses (table 3) may be due to the increase in the albumin concentration observed in a high number of animals (14 horses), as well as to the increase in the

Table 3. Median and interquartile range of the total protein concentration $(\mathrm{g} / \mathrm{L})$, serum protein fractions $(\mathrm{g} / \mathrm{L})$ and albumin/globulin ratio (A/G) from Group I (healthy horses) and Group II (horses suffering from babesiosis). Statistical differences between both groups are shown.

Mediana y rango intercuartílico de la concentración de proteínas totales $(\mathrm{g} / \mathrm{L})$, fracciones de proteínas $(\mathrm{g} / \mathrm{L})$ y cociente albúmina/globulina (A/G) del Grupo I (caballos sanos) y del Grupo II (caballos con babesiosis). Se muestran las diferencias estadísticas obtenidas entre ambos grupos.

\begin{tabular}{|c|c|c|c|c|c|c|c|c|c|}
\hline & & $\begin{array}{c}\text { Total } \\
\text { protein }\end{array}$ & Albumin & $\begin{array}{c}\alpha_{1^{-}} \\
\text {globulin }\end{array}$ & $\begin{array}{c}\alpha_{2-}^{-} \\
\text {globulin }\end{array}$ & $\begin{array}{c}\beta_{1^{-}} \\
\text {globulin }\end{array}$ & $\begin{array}{c}\beta_{2^{-}} \\
\text {globulin }\end{array}$ & $\begin{array}{c}\gamma- \\
\text { globulin }\end{array}$ & $\mathrm{A} / \mathrm{G}$ \\
\hline \multirow{2}{*}{$\begin{array}{l}\text { GROUP I } \\
(\mathrm{N}=19)\end{array}$} & Median & 6.00 & 3.21 & 0.12 & 0.53 & 0.65 & 0.41 & 0.94 & 1.05 \\
\hline & IQR & 0.60 & 0.44 & 0.05 & 0.23 & 0.25 & 0.42 & 0.29 & 0.35 \\
\hline \multirow{2}{*}{$\begin{array}{l}\text { GROUP II } \\
(\mathrm{N}=34)\end{array}$} & Median & 7.18 & 3.63 & 0.12 & 0.68 & 0.69 & 0.36 & 1.36 & 1.22 \\
\hline & IQR & 3.23 & 1.65 & 0.08 & 0.33 & 0.35 & 0.42 & 1.22 & 0.76 \\
\hline Significance level & & $\mathrm{P}<0.01$ & NS & NS & $\mathrm{P}<0.05$ & NS & NS & $\mathrm{P}<0.01$ & NS \\
\hline
\end{tabular}

$\mathrm{IQR}=$ interquartile range.

$\mathrm{NS}=$ non-statistically significant.

$\mathrm{NS}=$ no estadísticamente significativo. 
concentrations of $\alpha_{2}$-globulin and $\gamma$-globulin fractions discussed previously.

Results obtained in this study allow to conclude that the increase of the $\gamma$-globulin fraction, associated in some cases to the increase of the $\alpha_{2}$-globulin fraction, is a common finding in the serum electrophoresis of the horses suffering from babesiosis and it can be very useful for the diagnosis of the disease.

\section{SUMMARY}

Serum electrophoresis in cellulose acetate strips is a technique commonly used to separate the protein fractions. This technique allows detecting quantitative and qualitative changes in the serum proteins associated with different diseases. The aim of this study was to characterize the changes of the serum protein fractions produced in horses suffering from babesiosis and to evaluate its application in its diagnosis. Serum total proteins were calculated and the serum electrophoresis from 53 horses was performed. Animals were classified in two groups: Group I (19 healthy horses) and Group II ( 34 horses suffering from babesiosis). Babesiosis was diagnosed by indirect immunofluorescence antibody assay. Data obtained in the group of sick horses were compared with those from the healthy horses. Median values from total proteins and $\gamma$-globulins fraction were significantly higher $(\mathrm{P}<0.01)$ than that observed for the control group. In addition, a statistically significant increase was observed $(\mathrm{P}<0.05)$ in the values of $\alpha_{2}$-globulin subfraction in the sick horses. Results obtained in this study allow concluding that the most significant alteration observed in the serum electrophoretic pattern of horses suffering from babesiosis is the increase of $\alpha_{2}$-globulin and $\gamma$-globulin fractions.

\section{REFERENCES}

Asenzo G, S Wilkowsky, M Barrandeguy, M Mesplet, D Benitez, M Florin-Christensen. 2008. Development of an indirect ELISA for the diagnosis of equine piroplasmosis. Ann NY Acad Sci 1149, 235-238.

Barta O, SS Pourciau. 1984. Electrophoresis. In: Barta O (ed). Laboratory techniques of veterinary clinical immunology. Charles $\mathrm{C}$ Thomas, Illinois, USA, Pp 116-122.

Batamuzi EK, E Kristensen, AL Jansen. 1996. Serum protein electrophoresis: potential test for use in geriatric companion animal health programmes. Zbl Vet Med 43, 501-508.

Callow LL, W McGregor, BJ Rodwell, RJ Rogers, GG Fraser, DF Mahoney, GM Robertson. 1979. Evaluation of an indirect fluorescent antibody tests to diagnose Babesia equi infection in horses. Aust Vet $J$ 55, 555-559.

Carapeto MV, R Barrera, MC Mañe, C Zaragoza. 2006. Serum $\alpha$-globulin fraction in horses is related to changes in the acute phase proteins. J Equine Vet Sci 26, 120-127.

Colville J. 2002. Blood chemistry. In: Hendrix CM (ed). Laboratory procedures for veterinary technicians. $4^{\text {th }}$ ed. Mosby, St. Louis, USA, Pp 75-104.

Divers TJ. 1998. Liver failure: hemolitic anemia. In: Orsini JA, Divers TJ (eds). Manual of equine emergencies. WB Saunders, Philadelphia, USA, Pp 273-296.

Donnelly J, LP Joyner, C Frank. 1980a. Quantitative epidemiological studies on the prevalence of babesiosis in horses in Kuwait. Trop Anim Health Prod 12, 253-258.
Donnelly J, LP Joyner, O Graham-Jones, CP Ellis. 1980' . A comparison of complement fixation and immunofluorescent antibody tests in a survey of the prevalence of Babesia equi and Babesia caballi in horses in the Sultanate of Oman. Trop Anim Health Prod 12, 50-60.

Gornall AG, CJ Bardawill, MM David. 1949. Determination of serum proteins by means of the Biuret reaction. J Biol Chem 177, 751766.

Habela M, D Reina, C Nieto, SG Verdugo, I Navarrete. 1989. Epidemiología de la babesiosis equina en Extremadura: estudio preliminar. Med Vet 6, 1-7.

Hailat NQ, SQ Lafi, AM Al-Darraji, FK Al-Ani. 1997. Equine babesiosis associated with strenous exercise: clinical and pathological studies in Jordan. Vet Parasitol 69, 1-8.

Jain NC. 1993. The plasma proteins, dysproteinemias, and immune deficiency disorders. In: Essentials of veterinary hematology. Lea and Febiger, Philadelphia, USA, Pp 349-380.

Kaneko JJ, JW Harvey, ML Bruss. 1997. Clinical biochemistry of domestic animals. $5^{\text {th }}$ ed. Academic Press, New York, USA.

Kohn J. 1957. A cellulose acetate supporting medium for zone electrophoresis. Clin Chim Acta 2, 297-303.

Kumar S, DV Malhotra, AK Nichani. 2002. Identification of immunoreactive polypeptides of Babesia equi parasite during immunization. Vet Parasitol 107, 295-301.

Malikides N, JL Hodgson, AE Kessell. 2000. Practical Clinical Pathology. In: Rose RJ, DR Hodgson (eds). Manual of equine practice. $2^{\text {th }} \mathrm{ed}$. WB Saunders, Philadelphia, USA, Pp 593-620.

Morris DD, JK Johnston. 2002. Alterations in blood proteins. In: Smith $\mathrm{BP}(\mathrm{ed})$. Large animal internal medicine. $3^{\text {rd }} \mathrm{ed}$. Mosby, St. Louis, USA, Pp 427-433.

Navarrete I, FJ Serrano. 1999. Babesiosis. In: Cordero del Campillo M, Vázquez FA, Martínez AR, Sánchez MC, Hernández S, Navarrete I, Diez P (eds). Parasitología Veterinaria. McGraw-Hill Interamericana, Madrid, España, Pp 587-592.

Okamura M, N Yokohama, NP Wickramathilaka, N Takabatake, Y Ikehara, I Igarashi. 2005. Babesia caballi and Babesia equi: implications of host sialic acids in erythrocyte infection. Exp Parasitol 110, 406-411.

Okamura M, N Yokohama, N Takabatake, K Okubo, Y Ikehara, I Igarashi. 2007. Modification of host erythrocyte membranes by trypsin and chymotrypsin treatments and effects on the in vitro growth of bovine and equine Babesia parasites. J Parasitol 93, 208-211.

Radostits OM, CC Gay, DC Blood, KW Hinchcliff. 1999. Diseases caused by protozoa. In: Radostits QM, Gay CC, Blood DC, Hinchcliff KW (eds). Veterinary medicine. $9^{\text {th }}$ ed. WB Saunders, London, United Kingdom, Pp 289-1329.

Sevelius E, M Andersson. 1995. Serum protein electrophoresis as a prognostic marker of chronic liver disease in dogs. Vet Rec 137, 663-667.

Soule C, C Perret, P Dorchies. 1984. Babesiose equine a Babesia equi: comparison des techniques de fixation du complement d'immunofluorescence indirecte et ELISA. Rev Med Vet 135, 419-423.

Stockham SL, MA Scott. 2002. Proteins. In: Stockham SL, Scott MA (eds). Fundamentals of veterinary clinical pathology. Iowa State Press, Iowa, USA, Pp 251-276.

Thomas JS. 2000. Protein electrophoresis. In: Feldman BF, Zinnkl JG, Jain NC (eds). Schalm's veterinary hematology. $5^{\text {th }}$ ed. Lippincott Williams and Wilkins, Philadelphia, USA, Pp 899-903.

Tizard IR. 1996. Veterinary immunology an introduction. $5^{\text {th }}$ ed. WB Saunders, Philadelphia, USA, Pp 316-321. 